
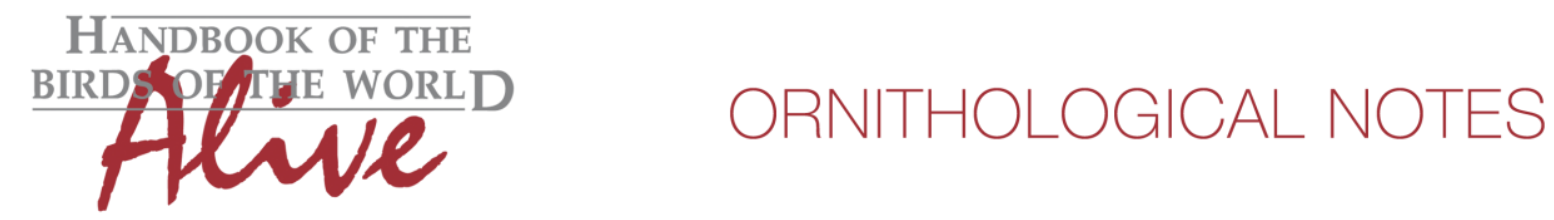

\title{
Notes on the vocalizations of Highland Elaenia (Elaenia obscura)
}

Peter Boesman

In the following we briefly analyze and compare voice of the two races of Highland Elaenia (Elaenia obscura). We also try to quantify the extent of any vocal differences using the criteria proposed by Tobias et al. (2010), as a support for taxonomic review.

We have made use of sound recordings available on-line from Xeno Canto (XC) and Macaulay Library (ML).

Rheindt et al. (2008) already indicated that the subspecies sordida better be treated as a separate species from $E$. obscura based on genetic distance, but apparently, a vocal analysis has not yet been performed.

There are quite some recordings available of (dawn) song, and it quickly becomes apparent that obscura and sordida have quite different vocalizations !

obscura

Song shows some variation, but always contains a similar base phrase "weehr-drrrr-whee" (consisting of an overslurred whistle, a rattle and again an overslurred whistle). Several elements can be added to this base phrase, such as very short notes and a rising burry whistle etc. (in rare cases the base phrase lacks the end whistle)(Fig. 1).

sordida

Song is a simple phrase repeated at intervals "wee-krrr-ee-krrree". It lacks seemingly any additional notes as in the more complex song of obscura (Fig. 2).

The base phrase of both races is very constant over their entire range, as can be seen from the examples (Fig. 1 and 2), and many differences can be listed:

$\begin{array}{llll}\text { obscura } & \text { sordida } & \text { score } \\ (\mathrm{n}=10) & (\mathrm{n}=7) & \\ \text { phrase length } & 0.68-0.76 \mathrm{~s} & 0.42-0.45 \mathrm{~s} & 3 \\ \text { longest note } & 0.32-0.41 \mathrm{~s} & 0.10-0.13 \mathrm{~s} & 3 \\ \text { min. freq. } & 900-1400 \mathrm{~Hz} & 680-890 \mathrm{~Hz} & 2 \\ \text { max. freq. 1st whistle } & 2900-3300 \mathrm{~Hz} & 2400-2800 \mathrm{~Hz} & 2 \\ \text { additional song notes } & \text { yes } & \text { no } & 1-2\end{array}$




\section{HANDBOOK OF THE \\ BIRD PF/THE WORLD \\ Alve}

\section{ORNITHOLOGICAL NOTES}

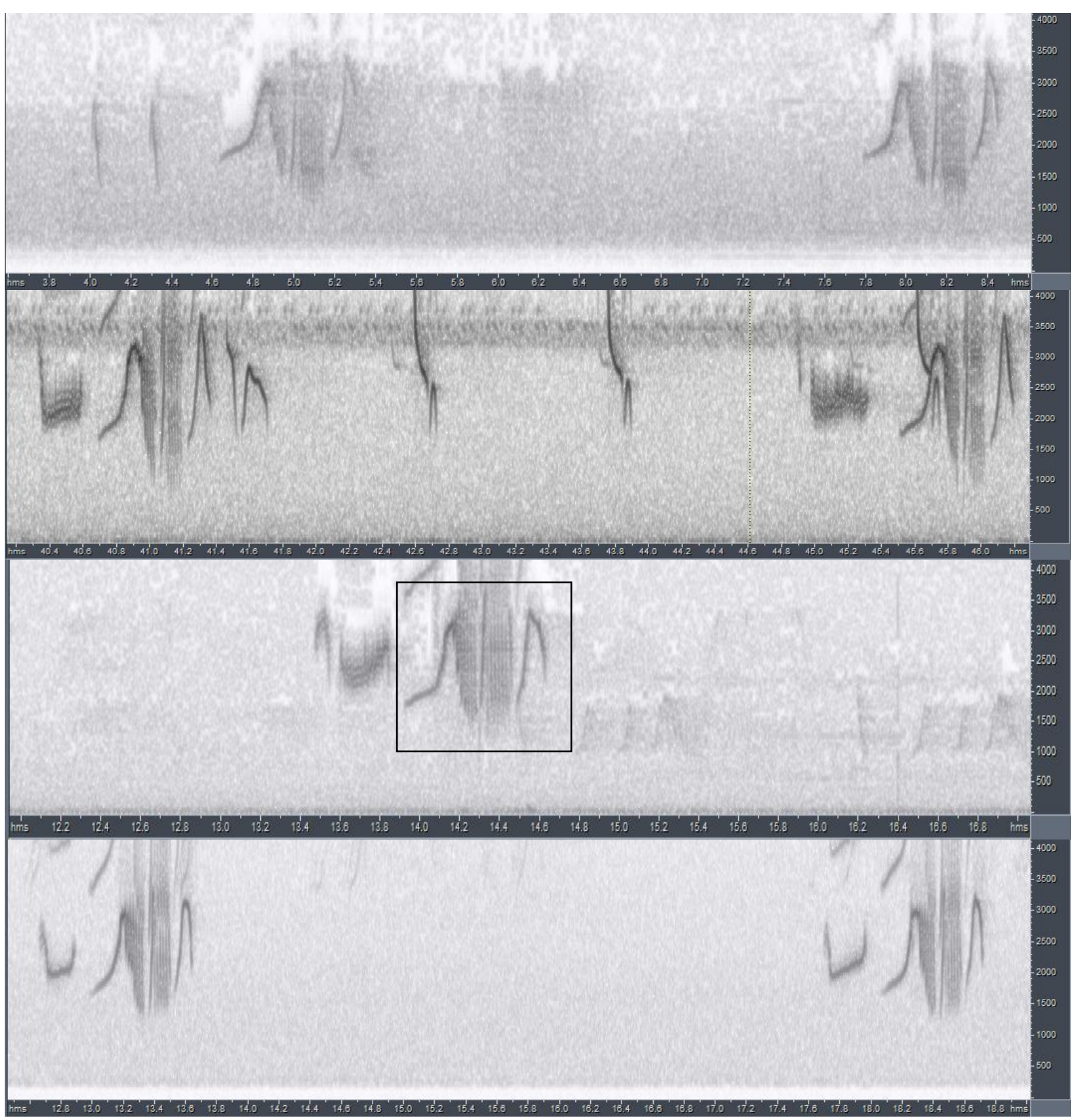

Figure 1: examples of typical song of race obscura, always containing the same base phrase (highlighted by a square on the 3rd sonogram) 


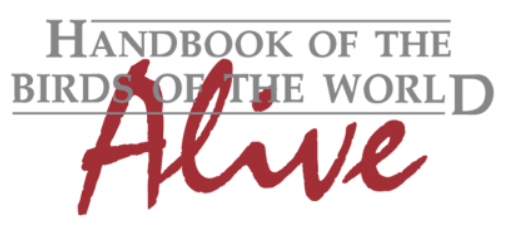

\section{ORNITHOLOGICAL NOTES}



Figure 2: examples of typical song of race sordida, always containing the same phrase

There seem to be equally important differences in call notes, but given it is already clear from the above that there is a score for vocal differences of at least 5 , we haven't examined those. 

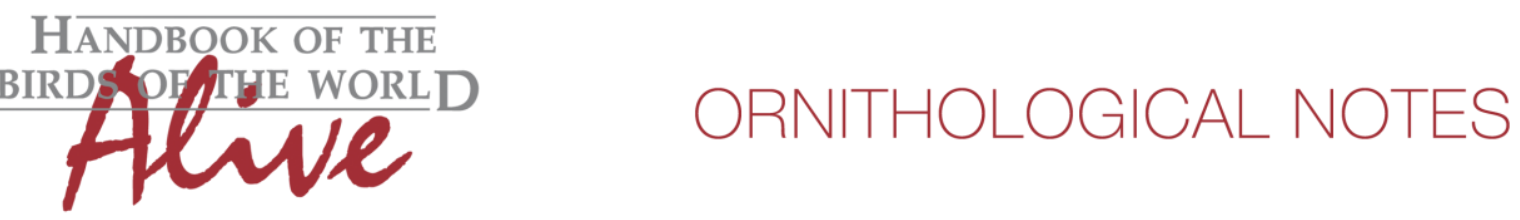

This note was finalized on 9th November 2015, using sound recordings available on-line at that moment. We would like to thank in particular the sound recordists who placed their recordings for this species on XC and ML: Juan Areta, Nick Athanas, Peter Boesman, Davis Finch, Bennett Hennessey, Fernando Igor de Godoy, Aidan Maccormick, Sjoerd Mayer, Jeremy Minns, Marcio Repenning, Heinz Remold, Mark Robbins, Fabrice Schmitt and Andrew Spencer.

\section{References}

Rheindt, F.E., Christidis, L. \& Norman, J.A. (2008). Habitat shifts in the evolutionary history of a Neotropical flycatcher lineage from forest and open landscapes. BMC Evol. Biol. 8: 1193

Tobias, J.A., Seddon, N., Spottiswoode, C.N., Pilgrim, J.D., Fishpool, L.D.C. \& Collar, N.J. (2010). Quantitative criteria for species delimitation. Ibis 152(4): 724-746.

\section{Recommended citation}

Boesman, P. (2016). Notes on the vocalizations of Highland Elaenia (Elaenia obscura). HBW Alive Ornithological Note 131. In: Handbook of the Birds of the World Alive. Lynx Edicions, Barcelona. (retrieved from http://www.hbw.com/node/932054 on 7 August 2016). 